\title{
C-4 STRUCTUAL MODEL OF CENTRAL EASTERN SICILY
}

MARIO BELLO and SAVERIO MERLINI Eni SpA Agip Division, Via Emilia 1, 20097 San Donato Milanese, Italy

\section{INTRODUCTION}

Seismic surveys in Central-Eastern Sicily are located mostly where hydrocarbon exploration is concentrated, namely Hyblean area to the South and the Nebrodi range to the North (Fig 1).

The recent acquisition of three regional seismic profiles in the central Sicily created a link between these two areas. This has supplied a lot of informations on the structural setting of this part of the Sicilian thrust belt, in combination with well $\log$, surface stratigraphic and structural data, magnetometric and gravimetric data and allowed us to define a new geo-structural model for this area.

\section{REGIONAL SETTING}

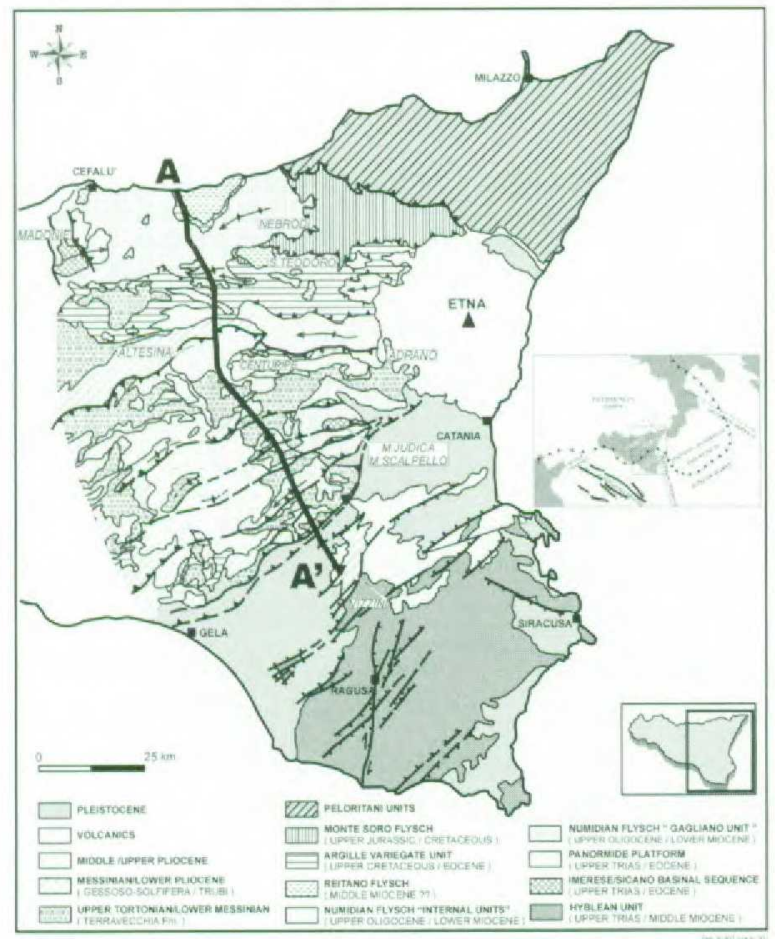

Fig. I geologic and structural map of central-eastern Sicily
Eastern Sicily is part of the Apennine Magrebian thrust belt, which resulted from the interaction between the African and European plates.

It is widely accepted that the Sicilian tectonic wedge is formed by the accretion of a series of sedimentary complex deposited on the African margin since the Triassic and on Neothetian oceanic crust since the late Jurassic.

In response to collisional process the sedimentary complexes were piled up during Paleogene-Neogene times and from the Middle Miocene they overthrusted the carbonate platform of the Pelagian block which is represented in the area by the Hyblean foreland. Three major structural elements separated by two major detachment levels form the 
Central Sicily thrust belt in the studied area (Fig. 2). The lowermost structural element is the mainly carbonate platform succession of the Hyblean unit. The Hyblean unit is overlain by two allochthonous structural elements

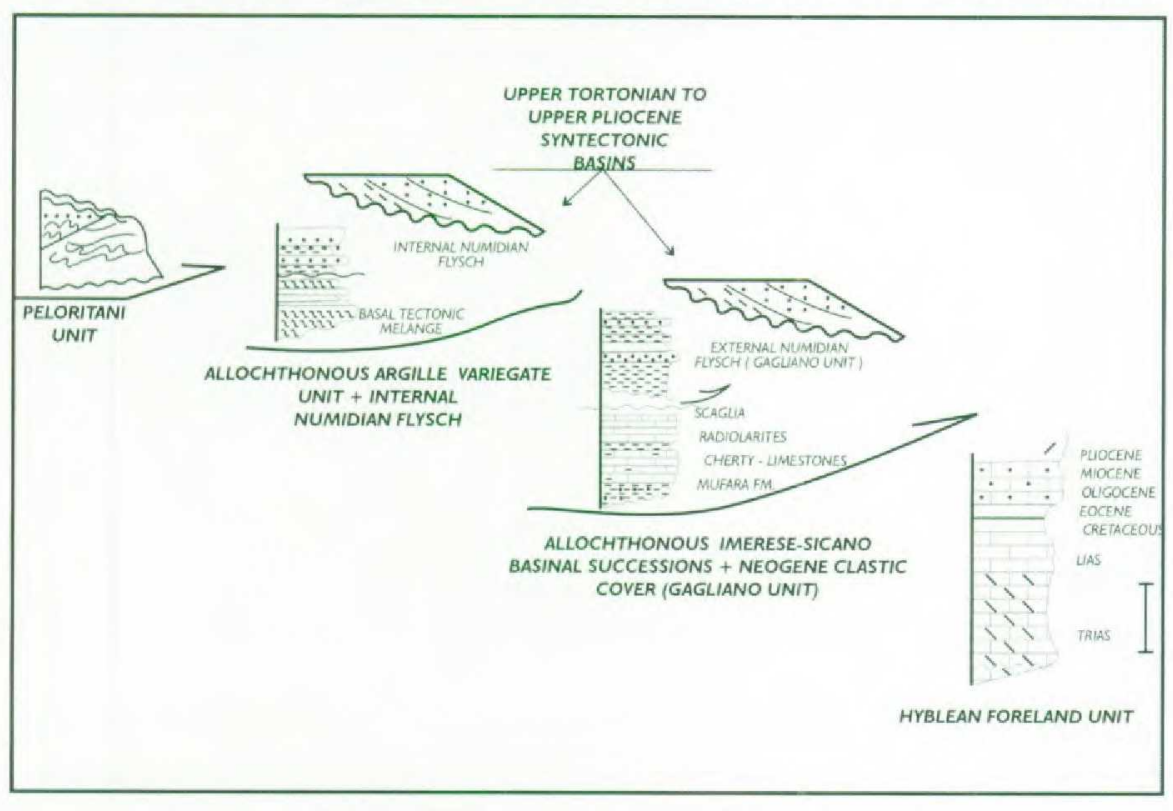

Fig.2 Tectono stratigraphic scheme for the central-eastern Sicily separated by a major detachment level. The lowest allochthonous element is composed of the Imerese-Sicano

Mesozoic basinal succession and its Neogene clastic cover (Numidian Flysch).

The highest structural element consist of an Upper Cretaceous to Lower Miocene

pelagic succession overlying a detachment zone with a varicoloured tectonic melange (Argille Variegate Unit)

All the allochthonous elements were emplaced during Late Oligocene to Early Miocene and re-deformed during the late Miocene to Pliocene by the propagation of deformation in the deeper structural unit as illustrate in the cross section (Fig. 3).

This section highlights the overall structural style of this segment of the Apennine-Maghrebian chain.

It is characterised by a generic thin-skin tectonic style with the basement not involved. This is corroborates by magnetometric data showing a possibly crystalline magnetic basement describing a monoclinal plunge toward the North. The southeastern end of the section shows the front of the wedge and the adjacent foredeep filled by Late Pliocene to Pleistocene deposits.

More to the NW, the tectonic element that marks the depression is a series of south verging thrust sheets involving Paleogene to Pliocene sediments. They constitute the "Gela nappe". This tectonic element lies on a detachment level located in Lower Pliocene sediments that unconformably cover the Hyblean unit. A NW dipping normal fault system affects the sequence of the Hyblean unit. The activity of this fault system must be ascribed to the late Pliocene as witnessed by the presence of a syndeformatonal Pliocene sedimentary wedge covering various fault blocks.

To the North the normal fault system is reactivated by early Pleistocene deep seated thrusts creating large compressional antiformal structures. These structures bend the basal detachment of the "Gela nappe".

In the northernmost part of the cross-section our main concern was to reconstruct the geometries of the allocthonous units. 
They consist mainly of thrusted folds with generally NE-SW trend (Fig. 2 and 3).

These folds indicate transport directions both towards the hinterland (NW) and the foreland (SE) of the belt.

The folds with general vergence toward the SE and their related thrusts create structures that ramp over Pliocene sediments covering unconformably the Hyblean unit.

These folds define a NW-SE trending structural high with a general plunge toward the SW. This high includes the partially outcropping folds of the Monte Judica Monte Scalpello area as well as the buried structure drilled by the wells Angelo 1 (Figs 1, 3). Folds with a general vergence toward the hinterland characterise the central part of the studied area and are bordered by large backthrusts.

The northernmost part of the area extends from the Madonie mountains to the village of $\mathrm{S}$. Teodoro. Here the Imerese-Sicano basinal succession is characterised by the presence of a series of NW dipping imbricated thrusts with associated south verging asymmetric folds bordered by reverse faults.

The imbricate fan thrust system and the backthrusts are located respectively in the backlimb and in the forelimb of a large fault bend anticline involving the Hyblean unit.

The simultaneous development of backthrusts and forethrusts in the allochthonous terrains created a series of structural depressions occupied by sintectonic basins filled with upper Tortonian-Middle Pliocene sediments.
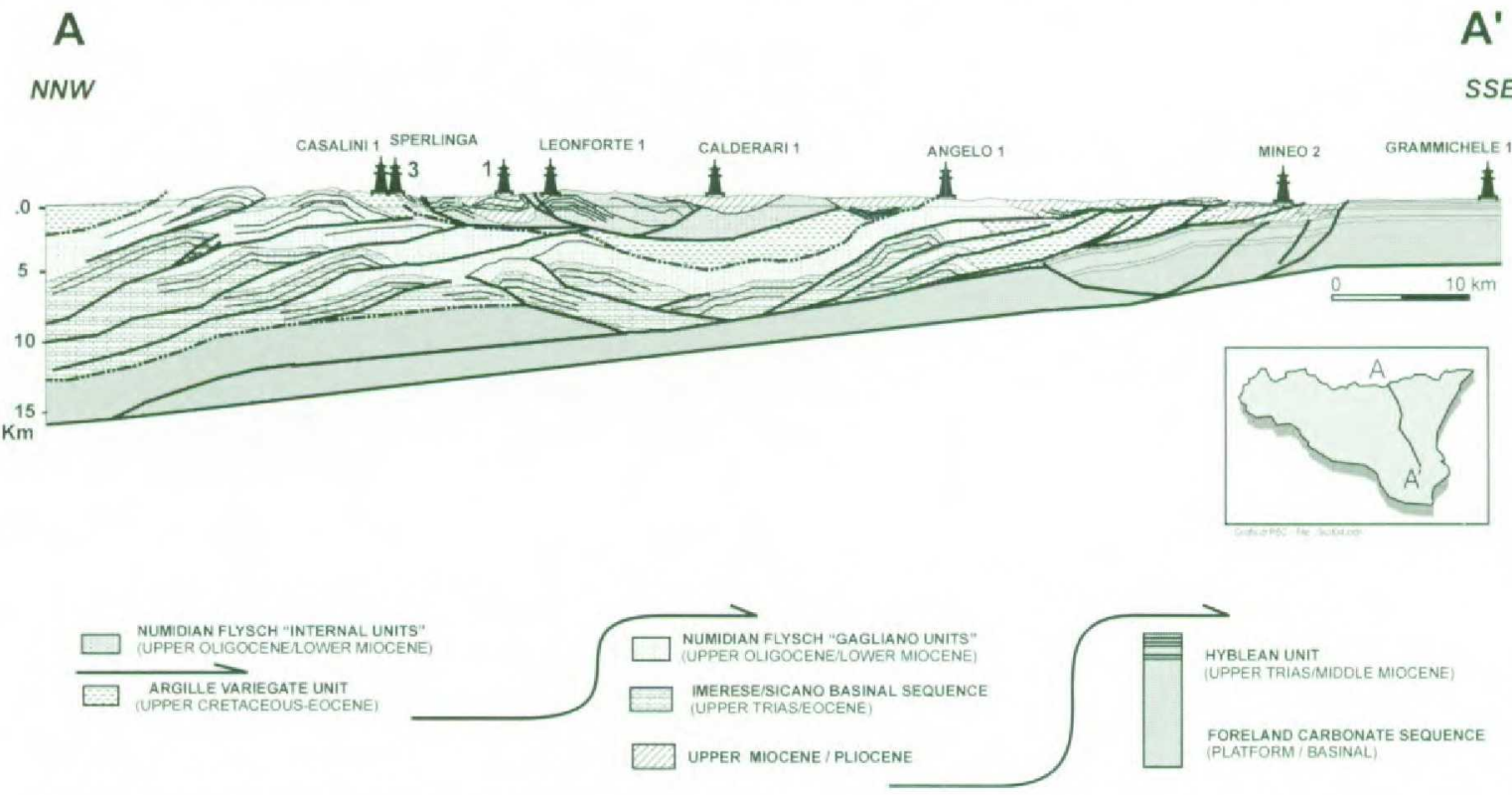

Fig. 3 Geologic cross-section of the eastern Sicilv

\section{STRUCTURAL MODEL}

The structural setting described before consists of three main structural elements separated by two main detachment levels overlying the crystalline magnetic basement

It is the result of two major tectinic phases. An initial tectonic phase from the lattermost Oligocene to the Middle Miocene creates the vertical assemblage of 
nappes described before (Fig. 4a). It is composed of a strong layer corresponing to the Hyblean Foreland unit.

The two allochthonous rock body, the Imerese-Sicano unit and The Argille Variegate unit represent weak layer (Fig. 4a).

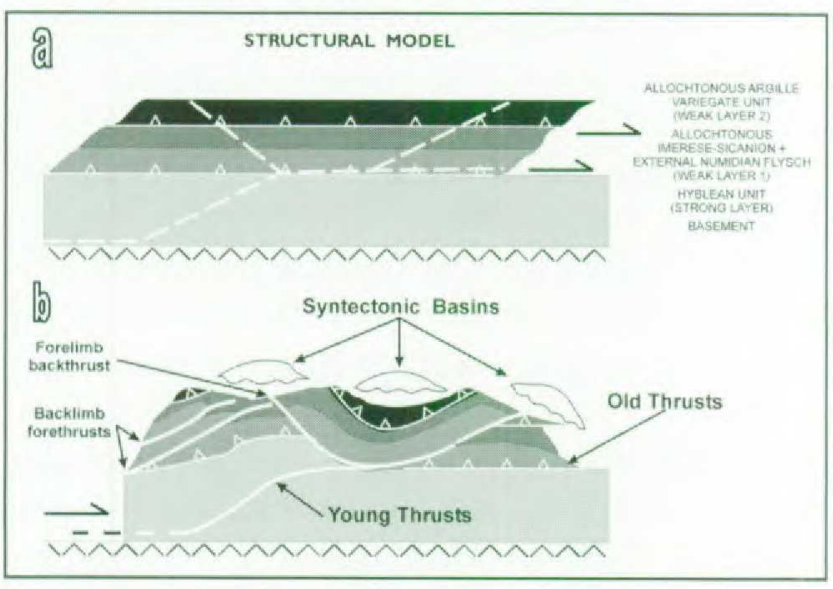

Fig.4 Kinematic sketch for the central-eastern Sicily
An Upper Tortonian to Pliocene deformational event involved the strong layer of the Hyblean Foreland Unit and modified the geometry of the two weak layers of the two allochthonous complexes. (Fig. 4b).

The pre-existing thrusts passively deformed by the development of newly formed thrusts. This is a consequence of both, the mechanical behaviour of the different structural units involved in the deformational event as well as the geometries of the pre existing thrusts that were approximately parallel to bedding

The tectonic assemblage can be considered as a multilayer where the preexisting tectonic features of the two weak layers are deformed by deep-seated thrusts that affected the strong layer.

This induces the development of secondary structures such as backlimb forethrusts and forelimb backthrusts.

Therefore the final NE-SW Anticlinorium-Sinclinorium pattern of the nappes edifice is the result of the interference between shallow and deep structures.

In this context (Fig. 3) the structures involving the Imerese-Sicano succession which were drilled by Angelo 1 well, are the result of the reimbrication and tilting of this previously emplaced allochthonous body due to the later deepseated thrust

The large backthrusts that are the dominant structural feature in the central part of the studied area, in the proximity of the Leonforte 1 well are interpreted as forelimb backthrusts that accommodate the shortening of the deeper structural unit in the higher structural levels.

The imbricate fan thrust system located in the northern of the studied area is interpreted as a series of backlimb forethrusts that reimbricates the previously emplaced tectonic wedge.

\section{SELECTED REFERENCES}

BIANCHI, F., CARBONE, S., GRASSO, M., INVERNIZZI, G., LENTINI, F., LONGARETTI, G., MERLINI, S. \& MOSTARDINI, F. (1987): Sicilia orientale: profilo geologico Nebrodi-Iblei. Mem. Soc. Geol. Ital., 38, 429-458

BUTLER, R.W.H., GRASSO, M. \& LA MANNA, F. (1992): Origin and deformation of the Neogene-Recent aghrebian foredeep at the Gela Nappe, SE Sicily. Journ. Geol. Soc. London, 149(4), 547-556

CASERO, P. \& ROURE, F. (1994); Neogene deformations at the Sicilian-North African plate boundary. - In: Roure, F. (ed.): Pery-Tethian Platforms. IFP Research Conf., Arles, Proceedings, 27-50 (Technip.)

DE FEYTER, A.\& MENICHETTI (1986); Back thrusting in forelimbs of rootless anticlines, with examples from the Umbro-Marchean Apennines (Italy). Mem. Soc. Geol. Ital., 35, 357-370

ROURE, F., HOWELL, D., MULLER, C. \& MORETTI, I. (1990): Late Cenozoic subduction complex of Sicily.Journ. of Struct. Geol., 12/2,259-266 